\title{
ACE-inhibitors, Beta-blockers or the Combination in Heart Failure: Is It Just an A-B-C ?
}

\author{
Editorial to: "Effects of beta-blockade and ACE inhibition on B-type natriuretic \\ peptides in stable patients with systolic heart failure" by Rosenberg et al.
}

\author{
Rudolf A. de Boer • Dirk J. van Veldhuisen
}

Published online: 17 April 2008

(C) The Author(s) 2008

During the last decades, the pharmacotherapy of heart failure (HF) has changed dramatically. Large-scale trials have been conducted that have indisputably shown the efficacy of angiotensin-converting enzyme inhibitors (ACE-I) and betaadrenergic receptor blockers ( $\beta$-blockers). These and other therapies have improved the overall outcome of patients with $\mathrm{HF}$, although prognosis remains bleak.

To identify patients with high risk for suffering a cardiovascular event or death, numerous (bio)markers have been put to test. (Serial) B-type natriuretic peptide (BNP) has emerged as a powerful surrogate parameter to monitor the severity of heart failure [1]. BNP can be measured easily and reliably [2] and currently, BNP is generally accepted as one of the strongest predictors for future events, death, and its use is advocated to monitor treatment [1].

In order for us to use BNP as a surrogate parameter at the full range of HF patients, we need to understand how $\mathrm{BNP}$ is regulated and what effects different drugs exert on BNP expression, production, and release.

BNP is expressed by ventricular, and to a lesser extent, atrial cardiomyocytes upon stretch [1]. On a clinical level, this is paralleled by mRNA levels that are directly related to parameters of severity of HF and to LV geometry [3]. On a molecular level, angiotensin II directly increases mRNA levels of BNP via posttranscriptional control of BNP [4, 5]. This in part mediated by a GATA element in the BNP promoter [6]. GATA elements are necessary and sufficient to confer transcriptional activation of BNP gene in response

R. A. de Boer · D. J. van Veldhuisen $(\bowtie)$

Department of Cardiology,

University Medical Center Groningen (UMCG),

PO Box 30.001, Groningen, The Netherlands, 9700RB

e-mail: d.j.van.veldhuisen@thorax.umcg.nl to hemodynamic stress [7]. So, angiotensin II seems to bring about increased expression of BNP, and this is paralleled with decreased BNP levels after institution of ACE-I and/or angiotensin receptor blockade [1, 8].

The beta1-adrenergic agonist isoproterenol stimulates BNP promoter activity by binding of nuclear protein to a GATA element [9]. So, do we fully understand what change in BNP level we can expect when we start a $\beta$-blocker in HF? Not quite. It has been observed $[10,11]$ that installment of the $\beta$ blocker metoprolol treatment in HF is not associated with a decrease in BNP levels, and in fact increases these levels.

In the current issue of the Journal, a substudy of the CARMEN shows that treatment with the $\beta$-blocker carvedilol alone is not associated with a decrease in BNP levels [12], while at the same time, (NT-pro) BNP predicts outcome. This study also shows, that treatment with an angiotensin converting enzyme (ACE) inhibitor, either alone or in combination with carvedilol, causes a decrease in these peptides. The fact, that ACE inhibition lowers BNP levels in patients with CHF has been reported before [13], as the authors point out, but a direct comparison between the two drugs and their combination on BNP levels present novel data.

The present study is therefore important for more than one reason. First, it shows that we should realize that there is an uncoupling of BNP levels and prognosis in HF patients who have been put on $\beta$-blockade just recently. It is beyond any doubt that $\beta$-blockers improve prognosis in patients with HF, but is also beyond any doubt that BNP levels reflect clinical status and prognosis in HF as well. What does this mean? It means that we should realize that a modest, transient increase in BNP levels should be accepted and regarded as a possible "side-effect" of $\beta$-blockade. There is work to do in determining how long this BNP increase lasts and what level of increase is still acceptable. 
Second, and maybe at least as important, this substudy of the CARMEN provides more data on whether treatment for HF might be initiated also with a beta-blocker instead of an ACE inhibitor [14]. It is common practice to start treatment of HF with an ACE-I and then add a $\beta$-blocker soon, and then other drugs [15]. This is because the large-scale trials have been conducted in this order and this is also advocated by HF guidelines. While there can be no discussion that the combination of an ACE inhibitor and a beta-blocker is by far the most effective drug regimen [16], the truth is that it often takes a long time after initiation of the first drug before the second drug is started. In addition, the first drug more often is uptitrated to the target dose, while the second drug is usually not. It is therefore important to analyze available data on this issue, and there are now three studies that have challenged this paradigm.

In the CARMEN (main) study [17], which examined the effects of drug therapy on left ventricular (LV) dilatation, combination therapy of an ACE inhibitor and a beta-blocker had the most pronounced effect on LV function, but betablockade alone was at least as effective as ACE inhibition alone. In the second study by Sliwa et al. [18] the betablocker carvedilol was in fact more beneficial than the ACE inhibitor with regard to exercise performance, functional class, but also N-BNP levels. In the largest comparative study so far, CIBIS-III [19], initiation of the beta-blocker bisoprolol for 6 months followed by 12 months combination therapy with an ACE inhibitor, was as effective as 6 months monotherapy with ACE inhibition, followed by another 12 months with the combination. Interestingly, in CIBIS-III beta-blockade was associated with slightly fewer sudden deaths, while slightly more patients had progression of HF, although neither of these effects was statistically significant. The present data, i.e. the fact that beta-blockade alone leads to an increase in BNP levels, may therefore be important in the light of these findings from CIBIS-III, since the two findings appear to be compatible. While it cannot be excluded that in CARMEN (and in CIBIS for that matter), uptitration of beta-blockade may have been "too much, too quick" (leading to increases in BNP and possibly to worsening HF), concurrent use of an ACE inhibitor is needed, as was again shown in the present study [12].

Open Access This article is distributed under the terms of the Creative Commons Attribution Noncommercial License which permits any noncommercial use, distribution, and reproduction in any medium, provided the original author(s) and source are credited.

\section{References}

1. Daniels LB, Maisel AS. Natriuretic peptides. J Am Coll Cardiol 2007;50:2357-68.
2. Tjeerdsma G, de Boer RA, Boomsma F, van den Berg MP, Pinto YM, van Veldhuisen DJ. Rapid bedside measurement of brain natriuretic peptide in patients with chronic heart failure. Int J Cardiol 2002;86:143-9.

3. de Boer RA, Henning RH, Suurmeijer AJ, Pinto YM, Olthof E, Kirkels JH, van Gilst WH, Crijns HJ, van Veldhuisen DJ. Early expression of natriuretic peptides and SERCA in mild heart failure: association with severity of the disease. Int J Cardiol 2001;78:5-12.

4. Suo M, Hautala N, Földes G, Szokodi I, Tóth M, Leskinen H, Uusimaa P, Vuolteenaho O, Nemer M, Ruskoaho H. Posttranscriptional control of BNP gene expression in angiotensin IIinduced hypertension. Hypertension 2002;39:803-8.

5. Majalahti T, Suo-Palosaari M, Sármán B, Hautala N, Pikkarainen S, Tokola H, Vuolteenaho O, Wang J, Paradis P, Nemer M, Ruskoaho H. Cardiac BNP gene activation by angiotensin II in vivo. Mol Cell Endocrinol 2007;273:59-67.

6. Bhalla SS, Robitaille L, Nemer M. Cooperative activation by GATA-4 and YY1 of the cardiac B-type natriuretic peptide promoter. J Biol Chem 2001;276:11439-45.

7. Marttila M, Hautala N, Paradis P, Toth M, Vuolteenaho O, Nemer M, Ruskoaho H. GATA4 mediates activation of the B-type natriuretic peptide gene expression in response to hemodynamic stress. Endocrinology 2001;142:4693-700.

8. White M, Lepage S, Lavoie J, De Denus S, Leblanc MH, Gossard D, Whittom L, Racine N, Ducharme A, Dabouz F, Rouleau JL, Touyz R. Effects of combined candesartan and ACE inhibitors on BNP, markers of inflammation and oxidative stress, and glucose regulation in patients with symptomatic heart failure. J Card Fail 2007;13:86-94.

9. He Q, Mendez M, LaPointe MC. Regulation of the human brain natriuretic peptide gene by GATA-4. Am J Physiol Endocrinol Metab 2002;283:E50-7.

10. Davis ME, Richards AM, Nicholls MG, Yandle TG, Frampton $\mathrm{CM}$, Troughton RW. Introduction of metoprolol increases plasma B-type cardiac natriuretic peptides in mild, stable heart failure. Circulation 2006;113:977-85.

11. Sanderson JE, Chan WW, Hung YT, Chan SK, Shum IO, Raymond K, Woo KS. Effect of low dose beta blockers on atrial and ventricular (B type) natriuretic factor in heart failure: a double blind, randomised comparison of metoprolol and a third generation vasodilating beta blocker. Br Heart J 1995;74:502-7.

12. Rosenberg J, Gustafsson F, Remme WJ, Riegger GAJ, Hildebrandt PR. The prognostic value of B-type natriuretic peptides during beta-blocker therapy in stable patients with systolic heart failure. Cardiovasc Drugs Ther 2008;22 (this issue).

13. van Veldhuisen DJ, Genth-Zotz S, Brouwer J, Boomsma F, Netzer T, Man In'T Veld AJ, Pinto YM, Lie KI, Crijns HJ. High- versus low-dose ACE inhibition in chronic heart failure: a double-blind, placebo-controlled study of imidapril. J Am Coll Cardiol 1998;32:1811-8.

14. Remme WJ. Should ACE inhibition always be first-line therapy in heart failure? Lessons from the CARMEN Study. Cardiovasc Drugs Ther 2003;17:107-9.

15. de Boer RA, van Veldhuisen DJ. Polypharmacy in chronic heart failure: practical issues regarding the use of angiotensin-converting enzyme inhibitors, beta-blockers and other drugs. Eur Heart J Suppl 2002;4(D):D111-6.

16. Komajda M, Lapuerta P, Hermans N, Gonzalez-Juanatey JR, van Veldhuisen DJ, Erdmann E, Tavazzi L, Poole-Wilson P, Le Pen C. Adherence to guidelines is a predictor of outcome in chronic heart failure: the MAHLER survey. Eur Heart J 2005;26:1653-9.

17. Remme WJ, Riegger G, Hildebrandt P, Komajda M, Jaarsma W, Bobbio M, Soler-Soler J, Scherhag A, Lutiger B, Rydén L. The benefits of early combination treatment of carvedilol and an ACEinhibitor in mild heart failure and left ventricular systolic dysfunction. The carvedilol and ACE-inhibitor remodelling mild 
heart failure evaluation trial (CARMEN). Cardiovasc Drugs Ther 2004;18:57-66.

18. Sliwa K, Norton GR, Kone N, Candy G, Kachope J, Woodiwiss AJ, Libhaber C, Sareli P, Essop R. Impact of initiating carvedilol before angiotensin-converting enzyme inhibitor therapy on cardiac function in newly diagnosed heart failure. J Am Coll Cardiol 2004;44:1825-30.
19. Willenheimer R, van Veldhuisen DJ, Silke B, Erdmann E, Follath F, Krum H, Ponikowski P, Skene A, van de Ven L, Verkenne P, Lechat P, CIBIS III Investigators. Effect on survival and hospitalization of initiating treatment for chronic heart failure with bisoprolol followed by enalapril, as compared with the opposite sequence: results of the randomized Cardiac Insufficiency Bisoprolol Study (CIBIS) III. Circulation 2005;112:2426-35. 